\title{
As cavernas em A caverna: dialética, alegoria e multiplicidade de sentido em José Saramago
}

\author{
Vanessa Cardozo Brandão*
}

\begin{abstract}
Resumo: Com base na referência à alegoria da caverna de Platão, o trabalho analisa a obra A caverna, de José Saramago, observando como o autor se apropria desse texto. Para discutir a(s) posição(ões) do autor, é utilizado o conceito de Walter Benjamin, tendo em vista que a construção alegórica configurase como fundamental na criação da multiplicidade de sentidos na obra. Essa análise procura destacar algumas estratégias textuais articuladas pelo autor em uma estrutura alegórica do romance, tais como o descritivismo, a construção cênica dos espaços narrativos e intertexto com ditos populares, que servem a um questionamento filosófico do lugar do homem na sociedade contemporânea. Assim, a análise busca perceber o projeto empenhado de literatura de Saramago, de uma ficção que se constitui espaço de questionamento do homem no mundo.
\end{abstract}

Palavras-chave: José Saramago; alegoria; dialética; estratégias autorais

\begin{abstract}
Based on Plato's allegory of the cave, this work analyses José Saramago's novel, The cave, observing how he used this text. In order to discuss Saramago's points of view, we used Walter Benjamin's concept of allegory, as the allegorization played a crucial role in the creation of a multimeaning work. This analysis intends to highlight some writing strategies, such as descriptivism, scenic construction of spaces and intertext with popular sayings, which serve as a form of philosophical questioning about the place of man in contemporary society. Thus, it is possible to see how Saramago's literary project turns fiction into a space for philosophical considerations of the world.
\end{abstract}

Keywords: José Saramago; allegory; dialectics; authorial strategies

Em A Caverna, a construção alegórica parte do mito platônico sobre o conhecimento e o insere no cotidiano frenético da sociedade de consumo atual. Essa mistura de filosofia antiga com atualidade, temperada por um estilo denso de escrita próprio do autor, faz de $A$ Caverna uma obra de particular importância no conjunto da escrita de Saramago.

O procedimento de alegorização, uma das marcas de Saramago, é fundamental em $A$ Caverna. Por isso, a importância de se retomar também o conceito de alegoria benjaminiano

\footnotetext{
* Vanessa Cardozo Brandão é Bacharel em Comunicação Social pela UFMG. É Professora da Faculdade de Comunicação e Artes na PUC Minas. Mestre em Literaturas de Língua Portuguesa pela PUC Minas e Doutoranda em Estudos Literários na UFF. Escreveu a dissertação: "Centro e margens literárias - alegoria e mito em A Caverna, de José Saramago". Sua tese "Caminhos da literatura - leitura metalingüística da temática da viagem como figuração do fazer literário na obra de José Saramago" está em elaboração.
} 
como operador dessa análise. Partiremos do conceito tradicional de alegoria e chegaremos a Walter Benjamin, que dá à alegoria um caráter de questionamento da suposta verdade romântica do símbolo. Benjamin resgata a alegoria característica do drama barroco e mostra como ela reaparece na modernidade.

Tomando como herança a tradição retórica, o romantismo evolui para um conceito redutor da alegoria, percebendo-a apenas como revestimento de uma abstração, em oposição ao símbolo, que teria um caráter de significação universal e unificador. Walter Benjamin apontou essa redução do conceito operada pelo romantismo e reivindicou um novo lugar para a alegoria enquanto forma de expressão. Estudado por Benjamin (1984) como expressão representativa do drama barroco alemão, o conceito de alegoria é para este autor mais do que uma simples técnica de ilustração. A alegoria benjaminiana é antes uma forma de expressão, como a própria linguagem escrita, que reflete um tipo de representação do mundo atrelada ao momento histórico da construção do discurso.

Em oposição à conciliação pacificadora entre ético e estético do símbolo romântico, derivada da separação de forma e conteúdo, Benjamin apresenta a riqueza dialética da alegoria. Mais do que ilustração concreta de um conceito abstrato, a alegoria deve ser compreendida como forma de expressão, e isso significa dizer que ela não cinde forma e conteúdo. A alegoria é expressão na linguagem, simultaneamente, dos elementos sensível e supra-sensível. Em oposição a um símbolo de interioridade não-contraditória, que unifica conteúdo ético na forma estética, a alegoria guarda sua riqueza expressiva no movimento dialético entre extremos. Acontece, pois, no movimento.

Essa dinâmica do sentido é fundamental para a compreensão e interpretação do elemento alegórico, já que ele expressa a impossibilidade de fixação da verdade, manifestando o conflito, o choque entre o desejo de eternidade e a consciência da precariedade do mundo. Esse caráter dialético, fruto da tensão do alegórico, é marca dos textos de José Saramago. Em A Caverna, essa visão alegórica recai sobre o sofrimento do homem que tem sua força de trabalho inutilizada em um universo capitalista, em que o mercado dita as regras de aceitação e inserção do humano no mundo dos objetos.

Particularmente, esse caráter antinômico da alegoria benjaminiana constitui um operador importante para a análise de A caverna. Em toda a obra, o autor parece trabalhar com um tipo de escrita alegórica que multiplica os sentidos, através de uma tensão dialética entre o ideal de uma sociedade em que o homem é elemento central (em detrimento dos objetos e imagens que ganharam o centro na sociedade capitalista) e a consciência da impossibilidade de escapar a esse mundo contemporâneo de imagens e representações. 
Como observa Maria Alzira Seixo (1987, p. 18), na obra de Saramago: "quase sempre, a arquitetura discursiva se bipolariza, mantendo como resultado uma tensão ideológica, ou a sua conversão através da ironia ou da conclusão (ou abertura) claramente moralizante".

$\mathrm{Na}$ análise ora realizada de A caverna, interessa-nos a visão da crítica sobre a tensão ideológica presente na obra do autor. Essa tensão manifesta-se na própria estrutura do romance, que oscila entre o ideal de centralidade do homem na sociedade e o descentramento das verdades através do jogo de desnudamento da atividade da escrita. O jogo do texto está nesse movimento, que impossibilita o fechamento de sentido, instigando o leitor à reflexão crítica. Assim, o autor cria uma obra que, como a apoteose barroca, é dialética e "se consuma no movimento entre os extremos" (BENJAMIN, 1984, p. 182).

Outra importante característica do texto de Saramago é sua vinculação histórica. Maria Alzira Seixo (1987) observa ainda que há na obra do autor:

um hábito de colocar em conjunção de interesses a dinâmica do tempo que se vive (seus acontecimentos, suas marcas específicas), a sensibilidade do sujeito que o vive e as potencialidades verbais suscetíveis de definirem essa mesma expressão - numa palavra, a qualidade literária do texto. (SEIXO, 1987, p. 13)

A utilização da literatura como lugar de reflexão do homem sobre si mesmo e seu lugar no mundo, marcante em toda a obra de José Saramago, ganha força em A caverna com o questionamento do cenário contemporâneo, o mundo dos objetos, das imagens e simulações que ganham importância em relação à humanidade.

Essa reflexão sobre a história é também traço importante da alegoria de Benjamin. Em oposição ao ideal de eternidade que o símbolo encarnava, a alegoria reabilita a temporalidade e a historicidade. Confrontado com o caráter efêmero do mundo, o alegorista expressa seu conflito, expondo a história como a história mundial do sofrimento. Por isso, Benjamin alerta para o fato de a alegoria ser forma de expressão comum em episódios históricos de declínio: "Nisso consiste o cerne da visão alegórica: a exposição barroca, mundana, da história como história mundial do sofrimento, significativa apenas nos episódios de declínio" (BENJAMIN, 1984, p. 188).

Escrita da ruína, a alegoria guarda significação em cada fragmento, o que faz com que o sentido ganhe multiplicidade. O olhar melancólico do alegorista combina os fragmentos e os faz acumular em um texto múltiplo, ambíguo, de uma riqueza de significação oposta à unicidade orgânica do símbolo. A síntese operada pela escrita alegórica "deve ser vista menos como uma paz, que como uma tregua dei entre duas intenções antagônicas" (BENJAMIN, 1984, p. 199). 
Em A caverna, a narrativa do destino da família Algor, desde o princípio marcada pela tragédia da recusa dos produtos da olaria pelo Centro, é toda ela uma alegoria que faz aparecer uma determinada "história mundial do sofrimento": o sofrimento e o abandono do homem frente ao reinado das imagens e dos objetos na sociedade capitalista:

Do que realmente aqui se irá tratar, sem grandezas nem dramas, é de levar ao forno e cozer
meia dúzia de estatuetas insignificantes para que reproduzam, cada uma delas, duzentas suas
insignificantes cópias, há quem diga que todos nascemos com o destino traçado, mas o que
está à vista é que só alguns vieram a este mundo para fazerem adões e evas ou multiplicarem
os pães e os peixes. (SARAMAGO, 2000, p. 173).

Resumindo o romance, o narrador ironicamente apresenta a história que aparece em primeiro plano na obra: o romance trata apenas do processo de fabricação dos bonecos pelo oleiro Cipriano, "sem grandezas nem dramas". No entanto a intenção alegórica da narrativa cria um segundo plano de construção de sentido. O trabalho de Algor na produção das estatuetas “insignificantes" é, na verdade, o pretexto para que se coloquem questões sobre a criação, o trabalho e a alienação do homem na sociedade contemporânea. Enquanto narra o processo de produção do oleiro, a voz autoral se interroga sobre o trabalho de criação humana de Algor, o trabalho de criação do mundo por Deus, e ainda o próprio trabalho de criação do mundo ficcional.

A ligação entre esses planos - plano do narrado, plano da interpretação alegórica e plano da narrativa - acontece através da estratégia metalingüística, que amplia a reflexão filosófica sobre o estar no mundo, característica de Saramago. O romance, assim, constitui travessia, espaço da reflexão e da busca que o homem realiza de si mesmo. A escrita ficcional apresenta-se como lugar de busca de respostas às questões existenciais, atravessando a narrativa da luta de Algor pela sua profissão, reflexões autorais sobre o mundo real, a situação do homem no mundo contemporâneo e ainda o mundo ficcional. Mundo ficcional que não se apresenta apenas como fingimento, tampouco como lugar da verdade e realidade. Antes o romance coloca-se num entre-lugar: mundo criado e de fingimento que, ao revelar suas máscaras, ganha potência para refletir sobre o mundo real.

Entretanto não é apenas na primeira grande narrativa da luta de Cipriano Algor pelo funcionamento da olaria que se estabelece o esquema de construção alegórica. Em A caverna, a estrutura alegórica reduplica-se em vários níveis do romance: na utilização da imagem da caverna platônica de maneiras variadas em todo o romance, em cenas de segundo plano, nas personagens, nas falas aforísticas do narrador, na construção cênica dos espaços, nas metáforas visuais, na própria forma de escrita e pontuação. Na estrutura alegórica, "cada pessoa, cada coisa, cada relação pode significar qualquer outra” (BENJAMIN, 1984, p. 197). 
No contexto alegórico de A caverna, não só personagens, mas todas as coisas, detalhes, objetos e palavras se apresentam como emblemas e podem significar outra coisa, fazendo da obra um emaranhado de estruturas de sentido antinômicos. A voz autoral parece trabalhar com a antinomia centramento $\mathrm{x}$ descentramento, refletindo sobre a posição do homem no mundo de imagens e representação.

\section{Imagens da escrita}

É importante aqui resgatar o caráter de "visualidade" da alegoria para Benjamin. Como alerta Kátia Muricy (1999, p. 174), "não se trata de vestir, por assim dizer, a essência de uma imagem. Trata-se, ao contrário, de fazê-la comparecer como imagem, apresentando-a como escrita [...] A essência aparece nua em sua materialidade de escrita, coisa sensória". Desse caráter da escrita, que se manifesta enquanto imagem em cada palavra, deriva a fragmentação no grafismo da obra alegórica. Assim, cada signo verbal do texto alegórico tem potencial de significação, fazendo do romance um amontoado de fragmentos significativos organizados sob o olhar do alegorista. Tal é o caráter visual, material, que Benjamin confere à alegoria no drama barroco alemão.

Essa visualidade pode ser percebida em A caverna sob vários aspectos. A começar pelo próprio estilo da escrita de Saramago: a pontuação peculiar, que resulta em parágrafos longos em que se encadeiam uma sucessão de falas, pensamentos de personagens, discurso do narrador, idéias e opiniões da voz autoral. Através dessa estratégia de pontuação, o texto de Saramago apresenta-se ao leitor em aparente desordem e, acima de tudo, como uma escrita que compõe um emaranhado de vozes em um texto apenas.

Essa escrita do fragmento, sem aparente ordenação, contribui para a inserção estratégica de fragmentos do pensamento autoral. Em trechos de A caverna, com uma dicção metalingüística, podemos ver que o narrador fala desse estilo de escrita autoral:

O inconveniente das divagações está na facilidade com que podem distrair por caminhos desviados o divagante, fazendo-o perder o fio das palavras e dos acontecimentos, como acaba de acontecer a Achado [...] (SARAMAGO, 2000, p. 143).

é o que têm de bom as associações de ideias, umas vão puxando pelas outras, de carreirinha, a habilidade está em não deixar perder o fio à meada, em compreender que um caco no chão não é apenas o seu presente de caco no chão, é também o seu passado de quando não o era, é também o seu futuro de não saber o que virá a ser. (SARAMAGO, 2000, p. 182).

Essa escrita da divagação, que caracteriza o estilo do autor, é aqui ironicamente tratada como um risco: o risco de se perder o fio dos acontecimentos no emaranhado textual. Analisando A jangada de pedra, Ivete Walty (1994) observa como Saramago trabalha na obra 
com o duplo sentido de risco da escrita: o risco gráfico que realiza um traçado no papel, separando a Península Ibérica da Europa, e também o risco da escrita do narrador. Riscos diferentes, mas que coincidem para a criação de um traçado da narrativa. A reflexão sobre o duplo risco da escrita também existe em A caverna, com a fala do narrador sobre o difícil trabalho de ordenação do texto.

Essa escrita de difícil ordenação, para a qual a pontuação não-convencional contribui, é propositadamente pensada pelo autor para projetar um efeito no leitor, segundo o próprio Saramago, que compara a convenção da pontuação com a convenção dos sinais de trânsito:

então o que eu acho é que, se o leitor, ao ler, está consciente disto, se sabe que naquela estrada não há sinais de trânsito, ele vai ter de ler com atenção, vai ter de fazer isso a que chamei uma espécie de "actividade muscular". E ele só pode entender o texto se estiver "dentro" dele, se funcionar como alguém que está a colaborar na finalização de que o livro necessita, que é a sua leitura. Isto que é verdade para todos os livros é muito mais verdade para um livro que se apresenta inacabado, com as costuras à vista. De certo modo pode dizer-se assim: os meus romances apresentam-se com as costuras à vista. (SARAMAGO apud REIS, 1998, p. 102)

Na escrita alegórica, a desordem do texto que se apresenta com as "costuras à vista" pede mais efetivamente a organização do leitor, de um leitor mais atento, que entre de fato no texto e faça a articulação, percebendo as múltiplas vozes dos personagens, do narrador, de outros textos, do autor. Essa é a exigência que os textos de Saramago fazem de seu leitor. Por causa da "desorganização" operada pela escrita multivocal, o leitor tem que se esforçar para ordenar o sentido, mas, curiosamente, estabelecer uma ordem que não se fixa e que está em constante movimento.

Além da pontuação, em A caverna outra estratégia é marcante como traço de "visualidade" da escrita alegórica por imagens. Há no romance um descritivismo dos espaços narrativos do Centro, da olaria e dos espaços intermediários. A narrativa descritiva fornece uma leitura visual desses espaços, em todos seus detalhes. Cada elemento, cada signo, aparece como pedaço constituinte de cenários que se abrem ao olhar do leitor, cada fragmento organizado na estrutura do texto para a composição do espaço:

Deixaram a Cintura Agrícola para trás, a estrada, agora mais suja, atravessa a Cintura Industrial rompendo pelo meio de instalações fabris de todos os tamanhos, actividades e eitios, com depósitos esféricos e cilíndricos de combustível, estações elétricas, redes de canalizações, condutas de ar, pontes suspensas, tubos de todas as grossuras, uns vermelhos, outros pretos, chaminés lançando para a atmosfera rolos de fumos tóxicos, gruas de longos braços, laboratórios químicos, refinarias de petróleo, amargos ou adocicados, ruídos estridentes de brocas, zumbidos de serras mecânicas, pancadas brutais de martelos de pilão, de vez em quando uma zona de silêncio, ninguém sabe o que se estará produzindo ali. (SARAMAGO, 2000, p. 13)

A enumeração de objetos e sons da área industrial é feita de forma condensada, apresentando-os como um conjunto desordenado de fragmentos que se (des)articulam ao olhar do leitor, fazendo-o "entrar" na obra, visualizar o cenário e quase sentir os cheiros dessa 
atmosfera, ouvir os ruídos que são descritos. Mais do que sentido, as imagens ganham corpo, matéria, com a descrição detalhada da Cintura Industrial.

Já estavam na periferia da cidade, haveria ainda que percorrer umas quantas ruas de traçado confuso, virar à esquerda, virar à direita, outra vez à esquerda, outra vez à direita, agora à direita, direita, esquerda, esquerda, direita, em frente, finalmente desembocariam numa praça a partir da qual se acabavam as dificuldades, uma avenida em linha recta levava-os aos seus destinos [...] (SARAMAGO, 2000, p. 17)

Na descrição do caminho, feita como a indicação de uma rota, a voz autoral realiza o detalhamento de cada direção do percurso, fazendo com que leitor entre na vertigem do texto e percorra junto das personagens cada virada do "traçado confuso" que leva ao Centro. É possível mais do que visualizar o caminho, ter a sensação de percorrê-lo, de entrar em cena junto das personagens.

Esse elemento cênico é outra importante característica do alegórico para Benjamin (1984, p. 214): “A alegoria manifesta-se tanto no elemento lingüístico como no figural e no cênico". Em A caverna, o aspecto cênico da obra é relevante e manifesta-se principalmente na importância dos espaços narrativos. Na caracterização de cada espaço - olaria, centro e lugares intermediários -, a descrição rica apresenta imagens que incorporam significados alegóricos atribuídos pela voz autoral.

Como na análise de Benjamin sobre o barroco, também em A caverna imagens de ruínas e de fragmentos da decadência apresentam-se com freqüência:

Entre as barracas e os primeiros prédios da cidade, como uma terra-de-ninguém separando duas facções enfrentadas, há um largo espaço despejado de construções, porém, olhando com um pouco mais de atenção, percebe-se no solo uma rede entrecruzada de rastos de tractores, certos alisamentos que só põem ter sido causados por grandes pás mecânicas, essas implacáveis lâminas curvas que, sem dó nem piedade, levam tudo por diante, a casa antiga, a raiz nova, o muro que amparava, o lugar de uma sombra que nunca mais voltará a estar. (SARAMAGO, 2000, p. 16)

O espaço intermediário, o caminho que Cipriano Algor precisa fazer várias vezes no romance para levar seus produtos ou buscar o genro no Centro, é rico em imagens de decadência, destruição e abandono. Essa “terra-de-ninguém”, que não se identifica nem com o ambiente natural da olaria nem com a organização artificial da cidade, é o campo intermediário entre olaria e Centro, vida e morte. Lembrando a relação que Marc Augé estabelece entre o surgimento dos "não-lugares" e a pós-modernidade, o espaço intermediário entre o Centro e a olaria é, de fato, um espaço criado, produzido pelo avanço da cidade:

Se um lugar pode se definir como identitário, relacional e histórico, um espaço que não pode se definir nem como identitário, nem como relacional nem como histórico definirá um não-lugar. A hipótese defendida aqui é a de que a supermodernindade é produtora de não-lugares, isto é, de espaços que não são em si lugares antropológicos e que, contrariamente à modernidade baudelairiana, não integram os lugares antigos [...] Os não-lugares, contudo, são a medida da época" (AUGE, 1994, p. 73). 
Aproxima-se dessa caracterização o espaço anteriormente descrito pelo narrador de Saramago, aparentemente, deserto e "despejado de construções". Mas não é vazio por ausência de ocupação. A vida que ali havia foi retirada, destruída pelas máquinas "implacáveis" que tudo levam: uma casa e um muro (imagens da habitação humana, metáforas do mundo da cultura/civilização), uma raiz e uma sombra (imagens da natureza, metáforas do mundo natural). Tudo é destruído pelos tratores para "limpar" o terreno, que separa as duas facções: cidade e margem. O espaço intermediário é não-lugar, produzido pela condição da contemporaneidade.

As imagens dos espaços intermediários são trabalhadas não apenas de forma a mostrar a potência avassaladora de avanço do urbano sobre o natural, mas também como forma de resistência:

No entanto, tal como sucede nas vidas, quando julgávamos que também nos tinham levado tudo por diante e depois reparamos que afinal nos ficara alguma coisa, igualmente aqui uns fragmentos dispersos, uns farrapos emporcalhados, uns restos de materiais de refugo, umas latas enferrujadas, umas tábuas apodrecidas, um plástico que o vento traz e leva, mostram-nos que este território havia estado ocupado antes pelos bairros de excluídos. (SARAMAGO, 2000, p.16).

Mesmo com a ação destrutiva dos tratores, em seu esforço de "limpar" o terreno e extinguir quaisquer vestígios de vida que ali existia, os fragmentos que restam são signos remanescentes que nos lembram da vida destruída. Sempre fica alguma coisa, o fragmento, de importância alegórica, para lembrar da ocupação que existia no terreno antes da forçada ausência de vida que se impôs:

Depois da Cintura Verde o oleiro tomou por uma estrada secundária, havia uns restos esquálidos de bosque, uns campos mal amanhados, uma ribeira de águas escuras e fétidas, depois apareceram numa curva as ruínas de três casas já sem janelas nem portas, com os telhados meio caídos e os espaços interiores quase devorados pela vegetação que sempre irrompe dos escombros, como se ali estivesse estado, à espera de sua hora, desde a abertura dos cavoucos. (SARAMAGO, 2000, p. 29).

Aqui também, o caminho percorrido por Algor é marcado pelas ruínas, pela decadência do que antes era natural e agora precisa sucumbir à expansão do espaço artificial da cidade, do Centro. O que se vê ali são "restos" abandonados, um cenário da deserção. A vida que antes havia é substituída por um cenário de morte, que se materializa no elemento linguístico através da escolha estratégica das palavras que descrevem o ambiente: na estrada "secundária”, "restos esquálidos”, “águas escuras e fétidas”, escombros de casas, com “telhados meio caídos". Mesmo nesse cenário de morte e abandono, a antinomia alegórica transparece em uma imagem que se apresenta: a vida ainda é capaz de brotar, como a vegetação que nasce dos escombros, resistindo pacientemente ao desígnio mórbido da região. 
Esse movimento entre vida e morte, através da imagem das ruínas e escombros nos espaços marginais na obra, é uma das mais importantes antinomias do romance.

Outra manifestação da antinomia alegórica, a metáfora visual é constante em $A$ caverna. Grande parte das metáforas trabalha com a tensão entre sujeito e objeto, derivada do desencanto autoral com a inversão de sentido na sociedade capitalista, que privilegia um reinado dos objetos. Maria Alzira Seixo já havia chamado atenção para a presença dessa temática no conto "Coisas", em Objecto Quase:

o conto [...] ocupa-se justamente de um processo de mutação dos homens em objectos e viceversa, terminando com a inevitável lição humanista de reconstrução: "Agora é preciso reconstruir tudo. / E uma mulher disse: - não tínhamos outro remédio, quando as coisas éramos nós. Não voltarão os homens a ser postos no lugar das coisas”. [...] A sua natureza [do conto] é mais claramente alegórica, quer pelo tipo de inversão de valores aqui praticado quer pela organização imediatamente ficcional adaptada.” (SEIXO, 1987, p. 28).

O ideal humanista de resgatar a centralidade do homem na sociedade é uma das marcas do romance A caverna. Esse ideal pode ser percebido nas metáforas abundantes que a voz autoral utiliza para comparar o homem a objetos:

Não vai ser fácil, uma pessoa não é como uma coisa que se larga num sítio e ali se deixa ficar, uma pessoa mexe-se, pensa, pergunta, duvida, investiga, quer saber, e se é verdade que, forçada pelo hábito da conformação, acaba, mais tarde ou mais cedo, por parecer que se submeteu aos objectos, não se julgue que tal submissão é, em todos os casos, definitiva. (SARAMAGO, 2000, p. 305)

Diferente dos objetos, as pessoas não devem ser facilmente manipuladas. Objetos são estáticos, ficam largados em cantos, mas o ser humano não: é de sua natureza pensar, questionar e agir. A seguir outra passagem em que a metáfora entre homem e objeto é utilizada: "Exposto assim, desarmado, com a cabeça caída para trás, a boca meio aberta, perdido em si mesmo, apresentava a imagem pungente de um abandono sem salvação, como um saco que se tivesse rompido e deixado escoar pelo caminho o que levava dentro." (SARAMAGO, 2000, p. 41).

A imagem de Algor dormindo é comparada a de um saco rompido que se esvaziara. Uma imagem de abandono, que torna visível a sensação de tristeza melancólica que a voz autoral pretende relacionar ao destino de Cipriano Algor, um homem de fato abandonado pela sociedade e excluído por causa da inutilidade de seu trabalho: "dizem eles que as loiças de barro deixaram de interessar, que já ninguém as quer, portanto, também nós deixamos de ser precisos, somos uma malga rachada em que já não vale a pena perder tempo a deitar gatos..." (SARAMAGO, 2000, p. 45).

Mais uma metáfora que compara o homem a um objeto, a imagem da tigela rachada comparada a Algor deixa à mostra a fragilidade e o abandono do sujeito na sociedade 
contemporânea, que não deseja perder tempo com pessoas que se tornaram descartáveis. Um pouco mais adiante, a comparação entre homem e objeto segue com outra imagem: "os mortos, alguém já o disse, são como pratos rachados em que não vale a pena enganchar aqueles também desusados grampos de ferro que uniam o que se tinha rompido e separado" (p. 45). Normalmente utilizando imagens de objetos extraídos do universo da cerâmica pratos, malgas, louças - a voz autoral compara homens, mortos ou vivos, aos objetos, denunciando a inversão de valores da sociedade contemporânea.

O ideal humanista do autor, que deseja a centralidade do homem e ao mesmo tempo tem a consciência da centralidade dos objetos na sociedade atual, transparece em outras metáforas visuais:

depois do que conversámos lá no cemitério pensei que não há grande diferença entre as coisas e as pessoas, têm a sua vida, duram um tempo, e em pouco acabam, como tudo no mundo. Ainda assim, se um cântaro pode substituir outro cântaro, sem termos de pensar no caso mais do que para deitar fora os cacos do velho e encher de água o novo, o mesmo não acontece com as pessoas, é como se no nascimento cada uma delas partisse o molde de que saiu, por isso é que as pessoas não se repetem. (SARAMAGO, 2000, p. 62).

Benjamin (1984, p. 246) fala sobre a consciência desse caráter efêmero da vida humana: "a visão da transitoriedade das coisas e a preocupação em salvá-las para a eternidade estão entre os temas mais fortes da alegoria". No diálogo entre Isaura e Cipriano, a similaridade entre objeto e sujeito está na efemeridade, no fato de ambos terem um tempo de duração, de vida no mundo. Coisas e pessoas são transitórias, entretanto a voz autoral faz uma distinção: comparado à imagem de um cântaro, o homem é visto como insubstituível, porque único. Sua singularidade, sua subjetividade, é exatamente o que o diferencia de qualquer objeto.

Mais uma passagem em que se metaforiza o elemento humano através de um objeto, na descrição de uma cena amorosa entre Marta e Marçal:

o que nessas ocasiões sucede é ter tomado o desejo conta absoluta do corpo para dele se servir, perdoe-se o materialista e utilitário símile, como se fosse de uma ferramenta de uso múltiplo e se tratasse, tão habilitada para deslizar como para lavrar, tão potente para emitir como para receber, tão minuciosa para contar como para medir, tão activa para subir como para descer. (SARAMAGO, 2000, p. 116).

O desejo sexual toma o corpo de Marçal, que é metaforizado na figura de uma ferramenta. O homem transforma-se em objeto de si mesmo, de seu próprio desejo. A sexualidade faz dele ao mesmo tempo sujeito e objeto do desejo. Como se percebe, em alguns momentos a tensão entre os dois pólos não implica a valorização de um deles, mas a convivência da duplicidade. Isso pode ainda ser observado na cena em que o narrador descreve a confusão de Algor sobre a cor de Achado, ao visualizá-lo no escuro da noite: 
e se de noite até os gatos brancos são pardos, o mesmo, ou em mais tenebroso, se poderia dizer de um cão visto pela primeira vez debaixo de uma amoreira-preta quando uma chuva miudinha e nocturna dissolvia a linha de separação entre os seres e as coisas, aproximando-os, a eles, das coisas em que, mais tarde ou mais cedo, se hão-de transformar. (SARAMAGO, 2000, p. 56).

O ideal de separação entre homens e coisas existe, mas convive com a consciência da voz autoral da inevitabilidade da transformação dos seres em objetos, mais cedo ou mais tarde.

Além das imagens que exploram a oposição entre sujeito e objeto, há em A caverna um conjunto de figuras que compõem um "caos de metáforas" representativas da linguagem alegórica. Para Benjamin, como expressão do conflito humano, do confronto entre o desejo de eternidade e a consciência de sua transitoriedade do mundo, a alegoria guarda como traço fundamental a antinomia. Na explosão de imagens alegóricas, cada coisa pode significar uma outra. Assim, o mundo profano é ao mesmo tempo exaltado e desvalorizado. Cada objeto pode ganhar uma significação importante no "caos de metáforas" que se estabelece com a irrupção constante de imagens alegóricas, ao mesmo tempo em que não passa de mero objeto sem importância entre tantos outros.

Um cântaro, uma amoreira-preta, um cão, um banco "das meditações", estatuetas de barro etc, em A caverna, cada significante tem potencial de manifestação de sentido, trabalhado cuidadosamente pelo autor. Característica marcante da alegoria, essa potencialidade infinita de sentidos realiza-se na escrita como matéria, assim como a descreve Benjamin:

o caráter precioso dessa forma de expressão (a alegoria), como do Barroco em geral, reside, ao contrário, em grande parte na regressão extrema ao nível de vocabulário concreto. A mania de empregar essas palavras, e de recorrer a antíteses elegantes, é tão marcada, que as abstrações, quando parecem inevitáveis, são acompanhadas de elementos concretos, formando novas palavras. (BENJAMIN, 1984, p. 221).

Algumas imagens alegóricas, recorrentes no romance, concretizam idéias abstratas veiculadas na voz do narrador. Metáfora do amor entre um homem e uma mulher - Cipriano e Isaura - o cântaro é significante de importância no romance: "Sendo assim fico-lhe muito agradecida, senhor Cipriano, Não tem de quê, Um cântaro novo é alguma coisa, Sim, mas é unicamente isso, só alguma coisa" (SARAMAGO, 2000, p. 47).

É com o pretexto de dar um cântaro novo a Isaura que Cipriano se aproxima da mulher que o atrai. A partir desse encontro, o cântaro, em oposição ao que diz Isaura, passa a ser muito mais que apenas uma coisa. É a concretização do desejo entre Algor e Isaura. A imagem, extraída do universo do oleiro - objeto de barro feito para guardar líquido - guarda 
semelhança visual com o feminino. Objeto artesanal, utilitário, assim como a vasilha de barro cozido descrita por Octavio Paz:

Sua beleza está aliada ao líquido que contém e à sede que sacia. Sua beleza é corporal: vejo-a, toco-a, cheiro-a, ouço-a. Se está vazia, é preciso enchê-la; se está cheia, é preciso esvaziá-la. Tomo-a pela asa torneada, como a uma mulher pelo braço, levanto-a, inclino-a sobre um jarro em que derramo leite ou pulque - líquidos lunares que abre e fecham as portas do amanhecer e do anoitecer, do despertar e do dormir. Não é um objeto para contemplar, mas para dar de beber. (PAZ, 1991, p. 45).

Essa utilidade do objeto artesanal, descrita por Octavio Paz, é metaforizada por Saramago na aproximação da imagem do cântaro com o corpo feminino. O desejo sexual faz do homem um objeto de si mesmo, o corpo do qual se serve para saciar o apetite da carne:

Como um cântaro profundo que lentamente se enche, a mulher vai-se aproximando do homem aos poucos e poucos, ou, talvez com mais rigorosa profundidade, fazendo-o aproximar-se dela, até que a urgência de um e a ansiedade do outro, já declaradas, já coincidentes, já inadiáveis, façam subir cantando a água unânime. (SARAMAGO, 2000, p. 114).

Aqui, a metáfora do desejo é explicitada, na comparação "como um cântaro que lentamente se enche". Mais do que coisa, o cântaro é emblema do amor, não apenas um amor romântico, mas amor carnal, desejo que arde entre Marta e Marçal no trecho acima, e ainda entre Isaura e Cipriano:

Não te escondas, deixa a tua filha em paz, ela só disse as palavras que querias ouvir, agora trata-se é de saber se tens para dar à Isaura Estudiosa algo mais do que um cântaro, e, também, não te esqueças, se ela está disposta a receber o que imaginas ter para lhe dar, se é que consegues imaginar alguma coisa. (SARAMAGO, 2000, p. 89).

Mais do que um cântaro, o que Cipriano deseja a oferecer a Isaura é a si mesmo, seu amor, que a personagem acredita ser pouco - "se é que consegues imaginar alguma coisa" (p. ??). Por isso evita aproximar-se de Isaura: um homem velho, que sequer consegue se manter com sua profissão, interroga-se a todo momento se pode viver esse amor. Em todo o romance, quando a imagem do cântaro se apresentar para Algor, ela trará consigo a dúvida dessa personagem sobre o desejo de viver o amor e a impossibilidade de realizá-lo, por se considerar incapaz: "Com o cântaro apertado contra o peito, Isaura Estudiosa olhou da sua porta a furgoneta que dava a volta para tornar o caminho andado, olhou o cão e o homem que conduzia..." (SARAMAGO, 2000, p. 63).

Ao ter o objeto consigo, Isaura guarda também um pouco de Cipriano, enquanto ainda não é possível a realização do amor entre eles. O cântaro aparece constantemente ao longo da narrativa como símbolo desse amor ainda irrealizado, para que outros acontecimentos relevantes sejam colocados em foco no romance. Nas palavras do narrador, esse objeto indica ao mesmo tempo o desejo e a separação, o desencontro de "duas pessoas objectivamente separadas por um cântaro" (SARAMAGO, 2000, p. 66). 
Somente após toda a frustrada tentativa de fabricação das estatuetas, a mudança para o Centro e o retorno à olaria, é que o encontro acontecerá e a metáfora será desnudada na fala da própria personagem:

Tens a tua casa, o teu emprego, E daí, Largar tudo assim, virar as costas, Já tinha largado tudo antes, já tinha virado as costas antes, quando apertei aquele cântaro contra o peito, realmente era preciso que fosses homem para não compreenderes que te estava a apertar a ti... (SARAMAGO, 2000, p. 348).

É Isaura quem cria coragem e propõe a viagem para longe da olaria. É também ela quem explicita o significado do objeto-cântaro em todo o romance: materialização de Cipriano para Isaura, e Isaura para Cipriano.

A amoreira-preta é outra imagem-metáfora recorrente na narrativa, materializando o sentido de natureza, proteção e abrigo, característicos do espaço da olaria. A imensa árvore frutífera é a primeira imagem que se apresenta no romance para indiciar a olaria: "A estrada fazia uma curva larga onde terminava a povoação, depois do último prédio via-se à distância uma grande amoreira-preta que não deveria ter menos de uns dez metros de altura, ali estava a olaria." (SARAMAGO, 2000, p. 29).

Elemento da natureza, a amoreira-preta é ícone da fertilidade que habita o espaço da olaria, espaço de criação em oposição ao cenário urbano da cidade e do Centro. Como a árvore do paraíso no mundo bíblico, símbolo da vida e do conhecimento do Bem e do Mal, a amoreira é a árvore que indicia a gênese, o lugar da criação no mundo ficcional. Dá frutos, é produtiva, como Cipriano e Marta na produção oleira artesanal. Será ela também um índice do fim da criação, com a condenação de morte à olaria:

dentro de uma semana tudo quanto estamos a ver aqui perderá grande parte do significado que tinha, a casa continuará a ser nossa, mas nela não viveremos, o forno não manterá o seu nome de forno se não houver quem lho dê todos os dias, a amoreira-preta persistirá em criar suas amoras, mas não terá ninguém que venha apanhá-las (SARAMAGO, 2000, p. 267).

Quando o trabalho da olaria é ameaçado, o que está em jogo é esse ideal de fertilidade que a amoreira-preta representa: de que adiantam o forno, a olaria, a amoreira-preta, se seus frutos não são colhidos? Para que servirá também o oleiro Cipriano? Essa é uma interrogação recorrente no romance sobre a inutilidade do homem na sociedade contemporânea.

Propositadamente, a voz autoral faz coincidir o nascimento da árvore com o da olaria:

morada e a olaria tinham sido construídas neste amplo terreiro, provavelmente uma antiga eira, ou um calcadoiro, no centro do qual o avô oleiro de Cipriano Algor, que também usara o mesmo nome, decidiu, num dia remoto de que não ficou registo nem memória, plantar a amoreira. (SARAMAGO, 2000, p. 30).

Por anos, a olaria funcionou e desenvolveu-se concomitante ao crescimento da amoreira-preta. Assistindo à passagem do tempo, a amoreira-preta é símbolo de resistência. 
No fio da narrativa, o tempo histórico transforma-se em tempo mítico. Marca do tempo original da família de oleiros, a árvore permanece através das gerações, guarda uma eternidade que a olaria não conseguiu, com a ameaça do fim do trabalho para a família Algor. Além de metáfora da produtividade, a amoreira-preta é ainda sombra, abrigo e proteção em diversos momentos: para o cão Achado, para as estatuetas produzidas, mesmo para Cipriano e Marta: "Estes seis bonecos, protegidos pela sombra da amoreira-preta, mas tocados de vez em quando pelo sol que se insinua e move por entre as folhagens". (SARAMAGO, 2000, p. 181).

Como imagem da natureza, ao mesmo tempo viva e dinâmica, mas também estável, congelada na paisagem da olaria, a amoreira-preta tem o conforto da permanência através do tempo, por isso, mais que oferecer sombra e proteção, o que ela oferece simbolicamente aos Algor é segurança, estabilidade, um ideal de continuação daquela vida da olaria através do tempo.

Outra função dessa imagem, no romance, é a de projetar sombra, fazer o jogo de claro e escuro, trevas e luz: "A folhagem compacta da amoreira-preta retinha a noite firmemente, não a deixaria ir-se dali tão cedo, o primeiro lusco-e-fusco do amanhecer ainda tardaria pelo menos meia hora." (SARAMAGO, 2000, p. 200).

No momento final da criação das estatuetas, a amoreira-preta tem o importante papel de reter a luz, enquanto as estatuetas ainda não terminam de cozer. É a amoreira (não por acaso preta) que perpetua a noite e a sombra até que finalmente os bonecos estejam prontos para nascer. No momento da gênese, fiat lux, a sombra cede. Para além do intertexto com o texto bíblico, o jogo de luz e sombra será ainda trabalhado pela voz autoral de outras maneiras, para remeter à alegoria da caverna de Platão.

Amoreira-preta, cântaros, malgas, estatuetas, ruínas e fragmentos: objetos convertidos em emblemas pela voz autoral, com objetivo de levar à construção de sentidos. Afinal, como diz Benjamin,

o objeto é incapaz, a partir desse momento, de ter uma significação, de irradiar um sentido; ele só dispõe de uma significação, a que lhe é atribuída pelo alegorista. Ele a coloca dentro de si, e se apropria dela, não num sentido psicológico, mas ontológico. Em suas mãos, a coisa se transforma em algo de diferente, através da coisa, o alegorista fala de algo diferente, ela se converte na chave de um saber oculto, e como emblema desse saber ele a venera. Nisso reside o caráter escritural da alegoria. (BENJAMIN, 1984, p. 106). 


\section{Frente e fundo - estrutura narrativa alegórica}

Ao estudar a alegoria como forma de expressão, Benjamin percebeu ainda algumas características da sua organização estrutural. Entre essas, além da metáfora, destacam-se o interlúdio alegórico e o freqüente uso de títulos e máximas.

O interlúdio é para Benjamin uma manifestação da simultaneidade das ações na alegoria. A estrutura que intercala narrativa de frente com outras de fundo, fazendo conviver na obra ação e coros da ação, o dito e o encenado, pode ser vista em A caverna. No primeiro plano, o tema do romance: o drama da família de oleiros que perde seu ganha-pão com a súbita recusa dos seus produtos pelo mercado. Em segundo plano, o questionamento sobre o mundo contemporâneo e a inversão de sentidos que ele realiza, ao transformar o homem em objeto na sociedade. O valor da estrutura alegórica está exatamente na forma como a voz autoral articula tema e significação, realizando um emaranhamento desses planos.

Em A caverna, a narrativa da tragédia da família Algor é entrecortada por várias outras narrativas, que reduplicam o tema gerando um freqüente questionamento sobre a sociedade capitalista contemporânea:

De tempos a tempos, por estas paragens, e em nome do axioma clássico que prega que a necessidade também legisla, um camião carregado de alimentos é assaltado e esvaziado em menos tempo do que leva a contá-lo. O método operativo, exemplarmente eficaz, foi elaborado e desenvolvido depois de uma aturada reflexão colectiva sobre o resultado dos primeiros intentos, malogrados... (SARAMAGO, 2000, p. 14).

No meio da descrição do caminho percorrido por Cipriano da olaria ao Centro, inserese uma segunda pequena história: a da marginalidade e da violência gerada pela "necessidade". A voz autoral interrompe a narrativa do percurso de Algor e Marçal para entrar com uma segunda narrativa, de como o grupo de excluídos arquiteta uma forma de conseguir alimentos. Estrategicamente colocada em espaços no meio, "entre-lugares" da narrativa central, essa outra história reafirma questões da primeira: mostra como essas ações marginais são formas de resistência e sobrevivência para um grupo de homens que vivem à margem da vida luxuosa do Centro e da cidade.

Essa estrutura do interlúdio reforça o estilo da escrita aparentemente desordenada porque fragmentada, tal como o pensamento que divaga. Ela replica-se em outros momentos do romance:

A mulher das barracas, aquela que precisava de pratos e púcaros novos, perguntou ao marido, Então, viste a furgoneta do olaria, e o marido respondeu, Sim, obriguei-a a parar, mas depois deixei-a seguir, Porquê, Tivesses tu olhado para a cara do homem que ia lá dentro, e aposto que terias feito o que eu fiz. (SARAMAGO, 2000, p. 24). 
Estranho, esse diálogo que corta a narrativa da recusa dos produtos de Algor pelo Centro tem um propósito estratégico na estrutura alegórica: além de mostrar a humanidade do 'ladrão' que roubaria a carga de Algor, que desiste de roubá-la quando vê a tristeza do oleiro, a ação serve para significar o quanto a decisão do Centro é devastadora. Reduplicando a estrutura da narrativa como um todo, essa pequena cena contém o indício do destino trágico do oleiro e de sua profissão. O ladrão é mais humano que o Centro, pois percebe a dor de Cipriano e demonstra compaixão.

A estratégia de inserir reflexões entre brechas da narrativa configura um estilo da escrita de Saramago, que cria situações paralelas à narrativa principal, em que personagens secundários aparecem, como 'figurantes', para fazer saltar aos olhos do leitor a defesa de uma idéia do autor, que se relaciona à temática de primeiro plano do romance:

\begin{abstract}
não teve o beneficiado muito de si com que agradecer, só a vulgar palavra obrigado, que tanto é sincera como não, e a surpresa de uma inclinação de cabeça nada de harmonia com a classe social a que pertence, o que isto quer dizer é que saberíamos muito mais das complexidades da vida se nos aplicássemos a estudar com afinco as suas contradições em vez de perdermos tanto tempo com as identidades e as coerências, que essas têm por obrigação explicar-se por si mesmas. (SARAMAGO, 2000, p. 26).
\end{abstract}

A cena do agradecimento do estranho que recebeu pratos e bilha de presente de Algor é toda ela uma construção alegórica, uma história encenada paralelamente à história 'principal' para que o autor discorra sobre a complexidade da vida. O narrador chama atenção para a forma 'supreendente' de agradecimento do beneficiado, para, a seguir, inserir um comentário interpretando essa atitude estranha como uma das complexidades e contradições da vida. Afinal, aparece aí a voz autoral para manifestar sua crença de que essas complexidades são o que realmente importa na vida.

Em outros momentos, a entrada da voz autoral, após uma cena-pretexto da narrativa, acontece através do pensamento da personagem da ação:

Não vão durar muito, pensou, desta vez referia-se às manufaturas, não ao futuro da atividade oleira, mas foi só porque não se deu ao trabalho de reflectir durante tempo suficiente, sucede isso muitos vezes, achamos que já se pode afirmar que não vale a pena esperar conclusões só porque resolvemos parar no meio do caminho que nos levaria a elas. (SARAMAGO, 2000, p. 28).

A reflexão rápida de Algor leva-o a uma conclusão precipitada, que é entrada para que o narrador nos alerte do perigo dessa precipitação do pensamento. A lição do autor, abstrata, transparece como conclusão de uma ação concreta da personagem, inserida na trama como veículo da visão de mundo do autor. Mais uma vez o procedimento alegórico que, ao narrar uma atitude objetiva da personagem, deixa espaço para que seja inserida uma reflexão autoral. 
Além do interlúdio alegórico, a presença constante de máximas e aforismos é outra característica da alegoria destacada por Benjamin, que é amplamente utilizada em A caverna:

Não raro, os diálogos são apenas as inscrições explicativas extraídas das configurações alegóricas em que as figuras se relacionam entre si. Nesse sentido, as sentenças podem ser chamadas "belas máximas intercaladas", como Klai as denomina no prefácio do drama de Herodes. Certas instruções são dadas por Scaliger para sua utilização. "As máximas e aforismos são os pilares do drama, mas não devem ser pronunciados por serviçais e pessoas de baixa extração, mas pelas pessoas mais nobres e idosas." Mas não somente as máximas emblemáticas, e sim discursos inteiros soam aqui e ali como se seu lugar fosse debaixo de uma gravura alegórica. (BENJAMIN, 1984, p. 219).

No romance de Saramago, o uso de aforismos e expressões populares é uma constante e, com freqüência, aparece na boca das personagens da família Algor. Na sabedoria da voz de Marta ou de Cipriano, essas máximas ganham novo sentido, reordenadas no contexto pelo desejo de significação da voz autoral. Essa apropriação das máximas, em um mecanismo de intertextualidade, constrói novos sentidos para as falas, as 'verdades' da cultura ocidental, com o efeito de levar o leitor ao questionamento de um olhar crítico.

Lembrando o sentido semiológico de mito de Barthes (2003, p.199), "o mito é uma fala", um sistema de comunicação, uma mensagem que se estrutura de acordo com uma determinada forma, um dado processo de significação que fecha o sentido de acordo com a apropriação feita pela sociedade. Nesse sentido barthesiano de mito, os ditos populares apropriados pelo autor em A caverna e ainda em outras obras podem ser considerados como mitos. Assim, A caverna reapresenta de forma crítica os mitos que ganham força enquanto discursos, graças à construção simbólica. No romance, isso é feito principalmente de duas maneiras: a desvalorização dos mitos do Centro (produtos e lugares) e sua caracterização enquanto simulacros, e ainda a desconstrução do sentido de ditos populares, pequenos mitos do saber acumulado na sociedade, constituídos na linguagem em frases de efeito. Em um momento, assim o narrador apresenta essas frases ao leitor:

Autoritárias, paralisadoras, circulares, às vezes elípticas, as frases de efeito, também jocosamente denominadas pedacinhos de ouro, são uma praga maligna, das piores que têm assolado o mundo. Dizemos aos confusos, Conhece-te a ti mesmo, como se conhecer-se a si mesmo não fosse a quinta e mais dificultosa operação. (SARAMAGO, 2000, p. 71).

O narrador aparece como veículo da voz autoral, questionando a validade das frases de efeito. A argumentação é clara e explícita, os ditos populares são colocados como "pragas" e é contestada a veracidade das afirmações que eles expressam: verdades que, distante de se aproximarem de uma essência das coisas, só existem porque são socialmente aceitas como fonte de conhecimento e sabedoria. 
A insensatez do dito é colocada à mostra pelo narrador, que primeiramente se apropria da frase com o sentido original para, logo à frente, desmascarar o enunciado e revelar a impossibilidade de se aceitar a verdade dessa fala socialmente instituída como tal:

Distraíra-se com a demolição dos prédios e agora queria recuperar o tempo perdido, palavras essas insensatas entre as que mais foram, expressão absurda com a qual supomos enganar a dura realidade de que nenhum tempo perdido é recuperável, como se acreditássemos, ao contrário dessa verdade, que o tempo que críamos para sempre perdido teria, afinal, resolvido ficar parado lá atrás, com a paciência de quem dispõe do tempo todo, que déssemos falta dele. (SARAMAGO, 2000, p. 20).

A relação da voz autoral com os ditos populares, no entanto, é bastante ambígua. Em vários momentos, os ditos são repetidos em sentido original, socialmente reconhecido. "Enquanto houver vida, haverá esperança" (SARAMAGO, 2000, p. 108) ou "assim é que a vida deve ser, quando um desanima, o outro agarra-se às próprias tripas e faz delas coração" (SARAMAGO, 2000, p. 177). Esses clichês, apropriados em seu sentido original sem crítica ou desvio, comumente aparecem nas falas das personagens, como se vê a seguir:

De qualquer modo barco parado não faz viagem, suceda amanhã o que suceder há que trabalhar hoje, quem planta uma árvore também não sabe se virá a enforcar-se nela, Com uma maré dessas é que o nosso bote não sai mesmo, disse Marta, mas tem razão, o tempo não está aí sentado à espera. (SARAMAGO, 2000, p. 152).

Marta olhara o pai primeiro cepticamente, como quem não estivesse a acreditar no que ouvia, mas aos poucos o rosto foi-se-lhe iluminando de compreensão, era o trabalho prestimoso da memória a trazer-lhe à lembrança certas expressões populares correntes, certos restos de leituras clássicas, certas imagens tópicas, é verdade que não recordou tudo quanto havia para recordar, por exemplo, queimar os barcos, cortar as pontes, cortar pelo são, cortar a direito, cortar as voltas, cortar o mal pela raiz, perdido por dez perdido por cem, homem perdido não quer conselhos, desistir à vista da meta, estão verdes não prestam, melhor um pássaro na mão que dois a voar, estas e muitas mais, e todas afinal para dizer uma só coisa. O que não quero é o que não posso, o que não posso é o que não quero. (SARAMAGO, 2000, p. 169).

Os ditos aparecem citados literalmente, mas o simples acúmulo dos mesmos em sequiências longas tem o poder de transfiguração do sentido original. Tal como a enumeração foi uma importante estratégia para criar o efeito de um excesso que produz vazio no espaço do Centro, o excesso de ditos também termina por provocar um esvaziamento no sentido original de cada um deles separadamente para recolocar um sentido fixado pela voz autoral no contexto da fala da personagem, em um processo de alegorização. A incorporação das frases de efeito ultrapassa, porém, as falas das personagens, invade a voz do narrador trazendo explicitamente a voz autoral: "Um amador de provérbios, adágios, anexins e outras máximas populares, desses já raros excêntricos que imaginam saber mais do que aquilo que lhe ensinaram, diria que aqui anda gato escondido com o rabo de fora." (SARAMAGO, 2000, p. 243). 
Em uma posição ambígua, o mesmo narrador que havia situado as frases de efeito como pragas assoladoras do mundo as reincorpora no texto para construção de sentidos sob a sua ótica. As vozes do texto caminham em direções diversas. Ora indicando uma aproximação com a narrativa da criação do mundo em Gênesis, ora invertendo o sentido dessa narrativa. Ao mesmo tempo, o autor aproxima o Centro da prisão da caverna platônica - universo do simulacro - e idealiza a olaria que, apesar de lugar de representação, é espaço do bem, da boa cópia. Faz isso ora criticando a verdade cristalizada e mitificada nos ditos populares, ora apropriando-se dessas verdades como veículo de sentido da voz autoral. Essa tensão mais uma vez assinala o movimento de incerteza da obra literária, da mobilidade de sentidos estabelecida por uma escrita polifônica que é, mais que um modelo de escrita literária, um modelo de toda a linguagem:

e então sentiu-se muito cansado, não por ter esforçado demais a mente, mas por ver que o mundo é assim mesmo, que as mentiras são muitas e as verdades nenhumas, ou alguma, sim, deverá andar por aí, mas em mudança contínua, não só não nos dá tempo para pensarmos nela enquanto verdade possível, como ainda teremos primeiro de averiguar se não se tratará de uma mentira provável. (SARAMAGO, 2000, p 91).

A suspeita da impossibilidade de localizar as verdades fixas aparece aqui na reflexão questionadora do narrador. Tal questionamento das verdades do mundo é realizado no romance através das estratégias textuais, entre elas, a alegoria. Importante lembrar o caráter de multiplicidade da alegoria, da impossibilidade de fixar sentido. O movimento da alegoria é o do "ritmo intermitente de uma pausa constante, de uma súbita mudança de direção, e de uma nova rigidez" (BENJAMIN, 1984, p. 221).

A linguagem fracionada da alegoria dá aos fragmentos expressões diferentes: não é apenas uma a imagem da caverna platônica no romance, mas várias. As máximas são apropriadas, mas ganham novos sentidos. Os espaços e personagens articulam-se no movimento entre olaria e Centro. Ganha força a antinomia, o movimento entre extremos: da crença humanista à consciência do reinado dos objetos na contemporaneidade, muitos são os conflitos manifestos pela visão autoral. Eles emergem em imagens igualmente conflituosas, em uma visão de mundo na obra que não é única, mas múltipla.

\section{Referências}

AUGÉ, Marc. Não-lugares - introdução a uma antropologia da supermodernidade. Tradução de Maria Lúcia Pereira. Campinas: Papirus, 1994. 
BARTHES, Roland. Mitologias. Tradução de Rita Buongermino, Pedro de Souza e Rejane Janowitzer. Rio de Janeiro: Difel, 2003.

BENJAMIN, Walter. Magia e técnica, arte e política - ensaios sobre literatura e história da cultura. Tradução de Sérgio Paulo Rouanet. São Paulo: Brasiliense, 1987. (Obras Escolhidas - v. I)

. Origem do drama barroco alemão. Tradução de Sérgio Paulo Rouanet. São Paulo: Brasiliense, 1984.

MURICY, Kátia. Alegorias da dialética. Imagem e pensamento em Walter Benjamin. Rio de Janeiro: Relume-Dumará, 1999.

MURICY, Kátia. Benjamin: política e paixão. In: NOVAES, Adauto (Org.) Os sentidos da paixão. São Paulo: Companhia das Letras, 1986.

PAZ, Octavio. Convergências - ensaios sobre arte e literatura. Tradução de Moacir Werneck de Castro. Rio de Janeiro: Rocco, 1991.

PLATÃO. A república. Tradução de Pietro Nassetti. São Paulo: Martin Clairet, 2003.

REIS, Carlos. Diálogos com José Saramago. Lisboa: Caminho, 1998.

SARAMAGO, José. A Caverna. São Paulo: Companhia das Letras, 2000.

SEIXO, Maria Alzira. O essencial sobre José Saramago. Lisboa: Imprensa Nacional - Casa da Moeda, 1987.

WALTY, Ivete Lara Camargos. O risco da escrita: uma leitura de A jangada de pedra, de José Saramago. In: Boletim do Centro de Estudos Portugueses da Faculdade de Letras da UFMG. V. 14, n. 17 (jan./jul. 1994). Belo Horizonte: Faculdade de Letras de UFMG, 1994. 